Crop Breeding and Applied Biotechnology 12: 17-24, 2012

Brazilian Society of Plant Breeding. Printed in Brazil

\title{
ARTICLE
}

\section{Phenotypic and molecular selection of yellow passion fruit progenies in the second cycle of recurrent selection}

\author{
Ronaldo Viana dos Reis ${ }^{1}$, Alexandre Pio Viana ${ }^{2 *}$, Eder Jorge de Oliveira ${ }^{3}$ and Marcelo Geraldo de Moraes Silva ${ }^{4}$
}

Received 8 December 2010

Accepted 10 February 2011

\begin{abstract}
The purpose of this study was to evaluate the efficiency of selection of a population of yellow passion fruit in the second cycle of recurrent selection, based on molecular and agronomic data. In 39 full-sib progenies, genotyped using microsatellite markers, 11 agronomic traits were evaluated. The progenies were selected based on the genetic distance matrix and the selection efficiency was confirmed based on the most important agronomic traits of yellow passion fruit. Only 12 of the 25 best progenies were identified by all three selection strategies (agronomic, molecular and combined selection). No significant correlation was observed between the genetic distance matrices and the molecular $x$ agronomic data. The progenies selected by molecular markers had the highest mean yield and fruit number. Results indicate the possibility of applying this combined selection procedure based on agronomic as well as molecular data to optimize genetic gain for the traits under selection.
\end{abstract}

Key words: breeding, Passiflora edulis, microsatellite markers, genetic variability.

\section{INTRODUCTION}

Brazil is the third largest fruit producer in the world, behind only China and India. In this context, the estimates of the Instituto Brasileiro de Geografia e Estatística (www.ibge.gov.br) indicate Brazil as the the leading position of Brazil in production, the annual national output is still very low $\left(10-15 \mathrm{t} \mathrm{ha}^{-1}\right)$, mainly due to the marginal use of crop-specific production technologies and insufficient supply of improved genotypes

In the production system, the lack of improved varieties hampers the production of homogeneous, high-quality fruit. Thus, research on the genetic improvement of passion fruit raises hopes that this

\footnotetext{
${ }^{1}$ Universidade Federal de Viçosa (UFV), Avenida PH Rolfs, s/n, 36.570-000, Viçosa, MG, Brazil

${ }^{2}$ Universidade Estadual do Norte Fluminense Darcy Ribeiro (UENF), Avenida Alberto Lamego, 2000, 28.013-600, Campos dos Goytacazes, RJ, Brazil.*E-mail: pirapora@uenf.br

${ }^{3}$ Embrapa Mandioca e Fruticultura, Rua Embrapa, s/n, 44.380-000, Cruz das Almas, BA, Brazil

${ }^{4}$ Instituto Federal do Norte de Minas Gerais, Fazenda São Geraldo, km 06, C.P. 97, 39.480-000, Januária, MG, Brazil
} 
situation can be changed. The breeding program of passion fruit of the Universidade Estadual do Norte Fluminense Darcy Ribeiro (UENF) began in 1998 with the collection of various genotypes from three different production regions in Rio de Janeiro state (Viana et al. 2003, Viana et al. 2004). Based on these initial studies, a larger commercial area was sampled in a second phase in the northern part of the state (Norte Fluminense). Based on the results obtained by means of designs I of Comstock and Robinson, it was decided to perform intrapopulation recurrent selection (Gonçalves et al. 2007, Silva et al. 2009). This method improves the population performance continuously and progressively, by increasing the frequency of favorable alleles of the traits under selection, maintaining the genetic variability that allows genetic gains in subsequent cycles.

Recurrent selection comprises the development and evaluation of a population, selection of the best plants and their use in the formation of a new parental population (Fehr 1987). In this last stage, it is essential that the selected progenies be divergent enough to ensure the restoration of genetic variability in the recombination process, underlying the continuity of the following cycles.

The selection of superior genotypes is normally based on the phenotypic evaluation of progenies. However, advances in the molecular marker technology have allowed the integration of information obtained on the basis of classical methods with molecular data.

Genetic variability is the basis underlying plant breeding, and since polymorphism can now be detected directly in DNA by molecular techniques (Milach 1998), some authors propose the use of this methodology to assess the diversity of the superior progenies identified in classical assessment for recombination (Popi et al. 2000, Tardin et al. 2007). Thus, based on the known level of genetic variability of a population and the greatest genetic distance between the plants, the genetic gains can be quantified. For some crops these procedures have been successfully adopted, optimizing the diversity in the selected parents (Townsend and Henning 2005).

Despite successful applications to economically important crops, in the case of passion fruit the use of molecular information at the different stages of recurrent selection has been limited. The purpose of this study was to use molecular and agronomic information of progenies of the second cycle of recurrent selection in a yellow passion fruit population to identify the best parents for recombination, with a view to maximize gains and genetic diversity.

\section{MATERIAL AND METHODS}

\section{Plant material}

Selected in the second cycle of recurrent selection, 39 full-sib progenies (called cycle 1 yellow passion fruit population - $\mathrm{PF}_{1}$ ) were evaluated (Silva et al. 2009). These 39 progenies were analyzed agronomically, in a randomized block design with five plants per plot in two replications, without controls at this stage of the program, assessed at a single location. In addition, molecular markers were used to select the best plants for recombination and formation of the new cycle of recurrent selection.

\section{Agronomic description}

The trial was installed in October 2006, in an experimental area of the Escola Agrícola Antônio Sarlo, in Campos dos Goytacazes, northern region of Rio de Janeiro state ( lat $21^{\circ} 45^{\prime}$, long $41^{\circ} 20^{\prime} \mathrm{W}$ and $11 \mathrm{~m}$ asl).

Silva et al. (2009) evaluated 11 agronomic traits: number of days to flowering (DF), fruit weight (FWe, in $\mathrm{g}$ ), fruit length (FL, in $\mathrm{mm}$ ), fruit width (FWi, in $\mathrm{mm}$ ), shell thickness (STh, in mm), total soluble solids (SS, in ${ }^{\circ}$ Brix), pulp color (PC on a color scale), pulp weight (PW, in g), number of fruits (NF), yield (YD, in $\mathrm{t} \mathrm{ha}^{-1}$ ) and mean fruit weight (MFWe, in g). Data normality was evaluated for all variables, to ensure the use of all traits in the subsequent analysis.

\section{Molecular characterization}

For this phase, the total genomic DNA was extracted from young leaves, as described by Doyle and Doyle (1990). The DNA quantity and quality were assessed by visual comparisons of fluorescence intensity of bands on $0.8 \%$ agarose gel stained with ethidium bromide, with known $\lambda$ phage DNA concentrations under ultraviolet light, diluted with ultrapure water and standardized at $5 \mathrm{ng} \mu \mathrm{L}^{-1}$.

Twelve microsatellite primers of the PE series (Passiflora edulis Sims), developed by Oliveira et al. (2005) were used (Table 1). Amplification reactions were performed in a total volume of $20 \mathrm{~mL}$, consisting of $20 \mathrm{ng}$ of genomic DNA, $50 \mathrm{mM} \mathrm{KCl}, 10 \mathrm{mM}$ Tris- $\mathrm{HCl}(\mathrm{pH}$ 
8.8), $0.1 \%$ Triton-X, $1.5 \mathrm{mM} \mathrm{MgCl} 2,100 \mathrm{mM}$ of each dNTP, $0.2 \mathrm{mM}$ of each primer and 0.5 units of Taq polymerase.

The amplifications were carried out in thermal cycler model PTC 100 (MJ Research). Two different touchdown amplification protocols were used, based on the programs TD60 ( 1 cycle at $94{ }^{\circ} \mathrm{C}$ for $5 \mathrm{~min}, 8$ cycles of $94^{\circ} \mathrm{C}$ for 40 seconds, $60^{\circ} \mathrm{C}-0.5^{\circ} \mathrm{C}$ per cycle for 40 seconds and $72{ }^{\circ} \mathrm{C}$ for $50 \mathrm{~s}, 24$ cycles of $94^{\circ} \mathrm{C}$ for 40 seconds, $56{ }^{\circ} \mathrm{C}$ for 40 seconds, $72{ }^{\circ} \mathrm{C}$ for $50 \mathrm{~s} ; 1$ cycle of $72{ }^{\circ} \mathrm{C}$ for $5 \mathrm{~min}$ ) and on TD56 ( 1 cycle at $94{ }^{\circ} \mathrm{C}$ for $5 \mathrm{~min}, 12$ cycles of $94^{\circ} \mathrm{C}$ for $40 \mathrm{~s}, 56 \mathrm{C}-0.5^{\circ} \mathrm{C}$ per cycle to 40 s, $72{ }^{\circ} \mathrm{C}$ for 50 s, 20 cycles of $94{ }^{\circ} \mathrm{C}$ for 40 seconds, $56{ }^{\circ} \mathrm{C}$ for 40 seconds, $72{ }^{\circ} \mathrm{C}$ for 50 s; 1 cycle of $72{ }^{\circ} \mathrm{C}$ for $5 \mathrm{~min}$. For the primer pair PE75, a specific annealing temperature of $60^{\circ} \mathrm{C}$ produced better results (Table 1). Consequently, the basic program consisted of an initial denaturation at $94^{\circ} \mathrm{C}$ for $5 \mathrm{~min}, 30$ cycles of $94{ }^{\circ} \mathrm{C}$ for $40 \mathrm{~s}, 60^{\circ} \mathrm{C}$ for $40 \mathrm{~s}, 72^{\circ} \mathrm{C}$ for $50 \mathrm{~s}$, and a final extension of $5 \mathrm{~min}$ at $72{ }^{\circ} \mathrm{C}$.

The fragments were separated on denaturing polyacrylamide gels (6\% polyacrylamide, $8 \mathrm{M}$ urea) under standard conditions, and amplification products were silver-nitrate-stained for allele visualization by the method of Creste et al. (2001).

\section{Statistical-genetic analyses}

The data of the agronomical assessment were subjected to analysis of variance using software Genes (Cruz 2006), applying the follo wing model
$Y_{i j}=m+G_{i}+B_{j}+E_{i j k}$

where $Y_{i j}=$ observation of the $\mathrm{i}^{\text {th }}$ progeny in the $\mathrm{j}^{\text {th }}$ replication; $m=$ general constant, $G_{i}=$ effect of the $\mathrm{i}^{\text {th }}$ progeny, being $\mathrm{i}=, 2, \ldots, g_{i}=g\left(g_{i} \approx N I D\left(0, \sigma_{g}^{2}\right)\right.$; $B j$ effect of the $\mathrm{j}^{\text {th }}$ block, being $\mathrm{j}=1,2, \ldots, \mathrm{r}$ $b_{j}=b\left(b_{j} \approx N I D\left(0, \sigma_{b}^{2}\right) ; \quad E_{i j k}=\right.$ experimental error $\varepsilon_{i j}=\left(\varepsilon_{i j} \approx N I D\left(0, \sigma^{2}\right)\right.$.

Later, these data were analyzed based on the Manhattan distance to indicate the variability of genotypes, using software Darwin 5.0 (Perrier et al. 2003). The Manhattan distance is given by $\mathrm{d}_{\mathrm{ij}}=\frac{1}{\mathrm{k}} \sum_{\mathrm{i}=1}^{\mathrm{k}} \frac{\left|\mathrm{x}_{\mathrm{ik}}-\mathrm{x}_{\mathrm{jk}}\right|}{\max _{\mathrm{k}}-\min _{\mathrm{k}}}$

where $X_{i k}$ and $X_{j k}$ are the values of variable $k$ for genotypes $i$ and $j ; \max _{k}-\min _{k}$ refers to the amplitude of variable $\mathrm{k}$; and $\mathrm{k}$ is the number of variables.

For molecular data, the distance matrix was calculated using Genes (Cruz 2006), based on the weighted index, given by $S_{i i '}=\frac{1}{2} \sum_{j=1}^{L} p_{j} c_{j}$, where $L$ is the total number of loci studied; $c_{j}$ is the number of common alleles between pairs of accessions $i$ and $i$ ' $p_{j}=\frac{a_{j}}{A}$; is the weight associated with locus $j$, given by $a_{j}=$ total number of alleles of locus $\mathrm{j}$; and $\mathrm{A}=$ total number of alleles studied, where $\sum_{\mathrm{j}=1}^{\mathrm{L}} \mathrm{p}_{\mathrm{j}}=1$.

From the sums of the matrices of the agronomic and molecular data, the combined matrix was calculated by $\mathrm{d}_{\text {ii }^{\prime}}=\frac{\text { Weighted index matrix }+ \text { Manhattan matrix }}{2}$.

Table 1. Microsatellite loci, primer sequence, motif, expected allele size (bp), polymorphic information content (PIC) and annealing temperature (AT) of the primers

\begin{tabular}{ccccccc}
\hline Locus & Forward primer & Reverse primer & Motif & bp & PIC & AT \\
\hline PE74 & ccctcttatcaatagcgttgg & gcacgagcacgagtatttatt & $(\text { ATCACA })_{5}$ & 215 & 0.33 & TD56 \\
PE38 & gatcggtcctcggttagac & agtcacacagcatgagaaatc & $(\mathrm{TG})_{8}$ & 215 & 0.24 & TD56 \\
PE58 & gcaatttcaccatcttctgct & ccacggtcatggatgttc & $(\mathrm{AC})_{11}$ & 243 & 0.10 & TD60 \\
PE11 & gcataagttgtcggtcttgg & cctcgaacctctatcatcca & $(\mathrm{GT})_{11}$ & 178 & 0.30 & TD60 \\
PE04 & atgctttggaaatccgttt & tgctcatgcaaagtcactgg & $(\mathrm{TG})_{9}$ & 235 & 0.05 & TD60 \\
PE24 & tcaaactgaactcgtaaagg & gtgctgggagactgatgtt & $(\mathrm{CA})_{15}$ & 294 & 0.20 & TD60 \\
PE66 & ccatagtccaacaagcatc & gctgtggaccctaactcagtc & $(\mathrm{AC})_{9}$ & 165 & 0.50 & TD60 \\
PE90 & tcaggaagattgcatgttagt & ctgggtttgtttatgttgc & $(\mathrm{AGC})_{5}$ & 245 & 0.05 & TD60 \\
PE18 & ccgtgaaccaaccatttctc & ttgcagcacaaacaagtcaa & $(\mathrm{TG})_{9}$ & 220 & 0.10 & TD60 \\
PE20 & aggatcaccatagaaaaccat & gttaggttggcattgctctt & $(\mathrm{AAAC})_{4}$ & 242 & 0.05 & TD60 \\
PE42 & gtcacttcattcttctttcc & ttagcccactcaaacacaa & $(\mathrm{GT})_{8}$ & 216 & 0.03 & TD60 \\
PE75 & cacaatcggtgggaaagata & gtagtttgggcagttgc & $(\mathrm{TG})_{17}$ & 178 & 0.17 & 60 \\
\hline
\end{tabular}


Then the hierarchical clustering UPGMA (Unweighted Pair-Group Method Using Arithmetic Average) was performed based on Manhattan distance matrices, the weighted index and combined selection, using the free software environment R (www.rproject.org). After analyzing the agronomical and molecular data and combined selection, the 25 most divergent genotypes were selected based on each of the methodologies, as a way of comparison. In addition, the dispersion of the six most important agronomic traits (YD, NF, SS, DF, PW and FWe), of selected genotypes was verified by the boxplot technique.

\section{RESULTS AND DISCUSSION}

For the traits evaluated, significant differences were observed among the 39 progenies by the F test for STh and SS at $1 \%$ probability and for FWe and FWi at $5 \%$ probability (Table 2). The differences for the traits DF, FL, PC, PW, NF, YD, and MFWe were not significant, although the data range indicated wide variation. The experimental accuracy (3.40 - $21.96 \%$ ), assessed by the coefficient of variation (CV), agreed with values obtained elsewhere for the traits of interest of this species (Viana et al. 2004, Gonçalves et al. 2007, Oliveira et al. 2008).

To guide the recombination and achievement of the best progenies, the 25 most divergent among the 39 genotypes were selected, as recommended by Silva et al. (2009). At this step of the program, the progenies selected in the previous cycle that consisted of 144 are subjected to an extra phenotyping, aiming at a small additional gain in the block of the new generation of full-sib progenies for the sequence of the intrapopulation recurrent selection. Based on this, the analysis was performed based on separate genetic distance matrices, i.e., the matrices obtained by agronomic and molecular data and combined selection. As a result, 15 selected genotypes (60\%) were common to the selection with agronomic and with molecular data, 20 genotypes (80 \%) coincided in the selection based on agronomic data and in combined selection (agronomic and molecular) and 18 genotypes (72\%) coincided based on the analysis of molecular data and combined selection. Only 12 genotypes (48\%) were common to all three selection strategies (Table 3).

The correlations between distance matrices of the agronomic data $\mathrm{x}$ combined selection and molecular data x combined selection were significant ( 0.56 and 0.81 , respectively) at $1 \%$ probability by the Mantel (1967)' test. On the other hand, the agronomic $\mathrm{x}$ molecular data showed were not significantly correlated (-0.02). Similar results were observed in other crops, e.g., oat (Moser and Lee 1994) and citrus (Koehler-Santos et al. 2003).

According to Souza and Sorrells (1991), the association between these matrices may be weak, maybe due to an inadequate representation of the genome by molecular markers or the absence of association between the loci that control the agronomic traits and microsatellite markers studied. In addition, this lack of association may be due to the fact that most of the variation detected by molecular markers is nonadaptive, unlike the phenotypic characteristics, which are affected by natural and artificial selection and interaction with the environment.

In an analysis of olive genotypes, Taamalli et al. (2006) demonstrated the existence of correlation

Table 2. Summary of analysis of variance for agronomic traits in 39 progenies of yellow passion fruit

\begin{tabular}{|c|c|c|c|c|c|c|c|c|c|c|c|c|}
\hline \multirow{2}{*}{$\begin{array}{l}\text { Source of } \\
\text { variation }\end{array}$} & \multirow[t]{2}{*}{ df } & \multicolumn{11}{|c|}{ Mean squares ${ }^{1}$} \\
\hline & & DF & FWe & FL & FWi & STh & SS & PC & PW & NF & YD & MFWe \\
\hline Progenies & 38 & 142.01 & $497.84^{*}$ & 31.34 & $11.02 *$ & $1.19 * *$ & $1.29 * *$ & 0.24 & 29.18 & 1961.90 & 13.68 & 184.23 \\
\hline mean & - & 115.30 & 170.03 & 82.78 & 75.26 & 6.45 & 12.00 & 4.12 & 39.51 & 195.04 & 20.51 & 148.92 \\
\hline MCI (95\%) & - & 24.52 & 39.20 & 9.36 & 5.92 & 1.42 & 1.86 & 0.75 & 10.54 & 104.26 & 4.86 & 33.18 \\
\hline CV (\%) & - & 12.05 & 9.90 & 5.30 & 3.40 & 11.82 & 5.22 & 11.21 & 11.43 & 21.96 & 18.67 & 8.08 \\
\hline $\operatorname{LSD}(5 \%)$ & - & 58.33 & 70.59 & 18.42 & 10.74 & 3.20 & 2.63 & 1.93 & 18.96 & 179.75 & 16.06 & 50.53 \\
\hline$h^{2}(\%)$ & & 34.70 & 66.30 & 58.70 & 83.05 & 40.70 & 45.90 & 19.50 & 54.90 & 36.60 & 28.50 & 71.30 \\
\hline
\end{tabular}

${ }^{1} \mathrm{DF}=$ Number of days to flowering; FWe = fruit weight; FL = fruit length; FWi = width of fruit; NF = number of fruits; YD = yield; $\mathrm{MFWe}=$ mean fruit weight; $\mathrm{STh}=$ shell thickness; SS = total soluble solids; $\mathrm{PC}=$ pulp color; $\mathrm{PW}=$ pulp weight. $* *$, $*$ : Significant at $1 \%$ and $5 \%$ of probability, respectively, by F test; MCI (95\%) = mean confidence interval at $95 \%$ probability; $\mathrm{CV}=$ coefficient of variation; LSD $=$ least significant difference $; \mathrm{h}^{2}=$ Broad-sense heritability. 
Table 3. Selected genotypes of the second cycle of recurrent selection of the UENF breeding program of yellow passion fruit using agronomic and molecular data and mixed data analysis

\begin{tabular}{|c|c|c|}
\hline Agronomic data & Molecular data & Mixed \\
\hline 14 & 10 & 10 \\
\hline 19 & 14 & 14 \\
\hline 23 & 19 & 23 \\
\hline 25 & 21 & 25 \\
\hline 40 & 23 & 26 \\
\hline 42 & 25 & 40 \\
\hline 44 & 26 & 42 \\
\hline 46 & 42 & 44 \\
\hline 48 & 44 & 46 \\
\hline 57 & 46 & 48 \\
\hline 64 & 48 & 64 \\
\hline 68 & 57 & 68 \\
\hline 89 & 64 & 70 \\
\hline 112 & 68 & 89 \\
\hline 117 & 70 & 112 \\
\hline 122 & 112 & 118 \\
\hline 123 & 118 & 122 \\
\hline 126 & 122 & 123 \\
\hline 129 & 127 & 129 \\
\hline 131 & 130 & 131 \\
\hline 133 & 132 & 133 \\
\hline 135 & 135 & 135 \\
\hline 140 & 137 & 137 \\
\hline 141 & 139 & 140 \\
\hline 144 & 144 & 144 \\
\hline
\end{tabular}

between agronomic and molecular data, although low (0.18 and 0.15 for AFLP and microsatellite data, respectively). Contrariwise, for common bean, Duarte et al. (1999) reported a correlation of 0.89 between genetic distances obtained by phenotypic data and RAPD markers, while Garcia et al. (1998) found a correlation of 0.79 in the analysis of 32 improved lines of melon. Such contradictions are common in the literature; there are reports that small distances estimated by molecular markers are associated with short phenotypic distances and that greater molecular distances are associated with both large and small phenotypic distances (Lefebvre et al. 2001). In addition, the apparent discrepancy between results may be explained by the characteristics of each species studied, by the type of agronomic traits and the number of markers used in the analysis of polymorphism.

In general, the lack of correlation between agronomic and molecular data in the yellow passion fruit progenies suggests that the two data types are suitable for a combined use, which can extend knowledge and discriminate the genotypes better for the recombination phase of progenies in the recurrent selection cycle.

In the case of passion fruit, the possibility of reducing the time required for the identification of superior individuals in breeding programs, especially in recurrent selection, has stimulated this study, with the purpose to explain the degree of agreement between the selection based on molecular and agronomic data. According to Lamkey and Lee (1993), the efficacy of selection may be more limited by the unreliability of trait screening than by any other factor. Therefore, any tool complementary to the selection strategies in segregating populations should be exploited to increase genetic gains.

Figure 1 shows the boxplots of the variation in the six main traits evaluated in selected progenies of yellow passion fruit in the second recurrent selection cycle, using agronomic and molecular data and combined selection. Although the means of the 25 selected progenies differed for most traits, the $t$ test only indicated significant differences for the traits NF and YD, at 1 and $5 \%$ probability, respectively, when compared with the selection based on agronomic $\mathrm{x}$ molecular data. There were no significant differences between the means of the six traits when selection was based on agronomic data $\mathrm{x}$ combined selection or on molecular data x combined selection (Figure 1).

The means for NF were $180.40 \pm 16.26,203.06 \pm$ 26.83 and $192.92 \pm 24.59$ fruits, when selection was based on agronomic and molecular divergence and combined selection, respectively. For the trait YD, the data ranged from $19.43 \pm 1.33,21.09 \pm 2.19$ and $20.48 \pm$ 2.08 in selection based on the genetic distance matrix of agronomic data, molecular data, and on combined selection, respectively.

Although the selection of genotypes using only agronomic data is being applied in passion fruit 
RV Reis et al.

improvement programs, even with significant genetic gains (Gonçalves et al. 2007, Silva et al. 2009), it was observed that the molecular data of divergence in the progenies was not only useful to maintain the genetic variability, but also to obtain greater gains in $\mathrm{NC}$ and YD, the most relevant traits in the selection
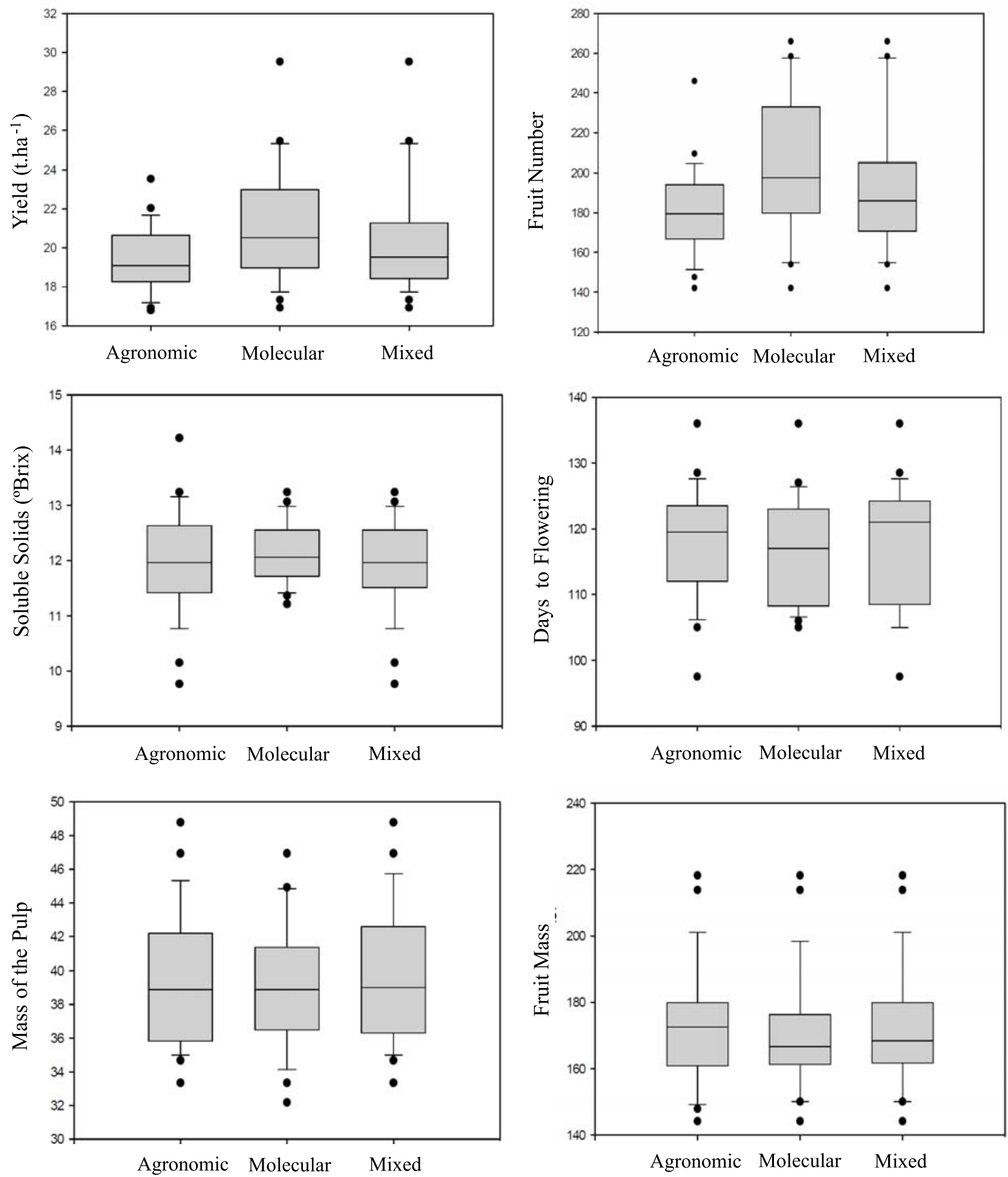

Figure 1. Boxplots related to the variation of six agronomic traits evaluated in 25 genotypes of yellow passion fruit, using agronomic and molecular data and combined analysis of these data. 
of superior parents for recombination or for release for cultivation.

The same strategy was used in maize, where it proved highly efficient to identify contaminant plants and to choose genotypes for recombination in order to maximize heterosis in recurrent selection programs, especially those with a view to the development of hybrids (Tardin et al. 2007).

On the other hand, the analysis of other traits of this study, based on molecular analysis, resulted in a slight reduction in fruit weight (170.03 \pm 12.06$)$, i.e, about $3 \mathrm{~g}$ less than selection based only on agronomic traits or on combined selection. The same applies to the trait number of days to flowering (116.36 \pm 7.31 ).

Information from the combined data analysis allowed a moderate gain for most of the traits evaluated, compared to selection based on agronomic and molecular data only. The reason was probably that combined selection identified several genotypes in common with agronomic and molecular data selection (Table 3). However, as the main goal at this stage of recurrent selection is to optimize time, money and genetic gain per generation, assessments of the agronomic performance and genotyping to identify the most divergent lines would increase the time - and cost-consumption for the recombination of the best progenies.

Selection procedures are of fundamental importance in recurrent selection, and in this respect, the identification of more divergent genotypes with greater yield potential is a top priority to ensure genetic gains without loss in variability. The plants for recombination can be identified in the competition assay of genotypes and the second cycle by the use of molecular markers. In this way, superior parents for recombination will be selected, with a higher frequency of favorable alleles and divergent enough to maintain genetic variability and greater exploitation of the heterotic effect in the repeated cycles of recurrent selection.

It is known that genetic divergence expresses the difference in the allele frequency of a population, and that the effect of the recombination of different alleles and types of gene action permits higher genetic gains, be it by exploring the additive effects to develop synthetic varieties or even by exploiting the allelic interactions of dominance and overdominance for the development of hybrids. Therefore, the use of molecular markers in early screening of the most promising plants for recombination has the advantage of optimizing the use of time and resources spent on breeding.

\section{ACKNOWLEDGEMENTS}

The authors thank the Foundation Carlos Chagas for Research Support of the State of Rio de Janeiro (FAPERJ) for funding this research.

\section{Seleção fenotípica e molecular de progênies de maracujazeiro amarelo no segundo ciclo de seleção recorrente}

Resumo - O objetivo desse trabalho foi avaliar a eficiência da seleção em uma população de maracujazeiro amarelo no segundo ciclo de seleção recorrente, com base em informações agronômicas e moleculares. Foram utilizadas 39 progênies de irmãos-completos, avaliadas para 11 características agronômicas e genotipadas por meio de marcadores microssatélites. As progênies foram selecionadas com base na matriz de distância genética e a eficiência da seleção foi verificada por meio das médias das características agronômicas de maior importância para a cultura. Das 25 melhores progênies selecionadas, apenas 12 foram comuns às três estratégias de seleção (agronômica, molecular e seleção combinada). Não foi observada correlação significativa entre as matrizes de distância genética com base nos dados agronômicos x moleculares. As progênies selecionadas pelos marcadores moleculares apresentaram maiores médias para produtividade $e$ número de frutos. Os resultados indicam a possibilidade de aplicação deste procedimento de seleção combinada com base em dados agronômicos e moleculares para otimizar os ganhos genéticos para os caracteres sob seleção.

Palavras-chave: melhoramento genético, Passiflora edulis, marcadores microssatélites, variabilidade genética. 


\section{REFERENCES}

Creste S, Tulmann Neto A and Figueira A (2001) Detection of single sequence repeat polymorphisms in denaturing polyacrylamide sequencing gels by silver staining. Plant Molecular Biology Reporter 19: 299-306.

Cruz CD (2006) Programa Genes - análise multivariada e simulação. Editora UFV, Viçosa, 175p.

Doyle JJ and Doyle JL (1990) Isolation of plant DNA from fresh tissue. Focus 12: 13-15.

Duarte JM, Santos JB and Melo LC (1999) Genetic divergence among common bean cultivars from different races based on RAPD markers. Genetics and Molecular Biology 22: 419-426.

Fehr WR (1987) Principles of cultivar development: theory and technique. Macmillan, New York, 536p.

Garcia E, Jamilena M, Alvarez JI, Arnedo T, Oliver JL and Lozano R (1998) Genetic relationships among melon breeding lines revealed by RAPD markers and agronomic traits. Theoretical and Applied Genetics 96: 878-885.

Gonçalves GM, Viana AP, Barros Neto FV, Pereira MG and Pereira TNS (2007) Seleção e herdabilidade na predição de ganhos genéticos em maracujá-amarelo. Pesquisa Agropecuária Brasileira 42: 235-240.

Koehler-Santos P, Dornelles ALC and Freitas LB (2003) Characterization of mandarin citrus germplasm from Southern Brazil by morphological and molecular analyses. Pesquisa Agropecuária Brasileira 38: 747-806.

Lamkey KR and Lee M (1993) Quantitative genetics, molecular markers, and plant improvement. In Imrie BC and Hacker JB (eds) Focused plant improvement: towards responsible and sustainable agriculture. Proc. $10^{\text {th }}$ Australian Plant Breeding Conference, Gold Coast, p. 104115.

Lefebvre V, Goffinet B, Chauvet JC, Caromel B, Signoret P, Brand R and Palloix A (2001) Evaluation of genetic distances between pepper inbred lines for cultivar protection purposes: comparison of AFLP, RAPD, and phenotypic data. Theoretical and Applied Genetics 102: 741-750.

Mantel N (1967) The detection of disease clustering and a generalized regression approach. Cancer Research 27: 209-220.

Milach SCK (1998) Marcadores moleculares em plantas. UFRGS, Porto Alegre, 141p.

Moser H and Lee M (1994) RFLP variation of genealogical distance, multivariate distance, heterosis and genetic variation in oats. Theoretical and Applied Genetics 87: 947-956.
Oliveira EJ, Pádua JG, Zucchi M I, Camargo LEA, Fungaro MHP and Vieira MLC (2005) Development and characterization of microsatellite markers from the yellow passion fruit (Passiflora edulis f. flavicarpa). Molecular Ecology Notes 5: 331-333.

Oliveira EJ, Santos VS, Lima DS, Machado MD, Lucena RS, Motta TBN and Castellen MS (2008) Seleção em progênies de maracujazeiro amarelo com base em índices multivariados. Pesquisa Agropecuária Brasileira 43: 1543-1549.

Perrier X, Flori A and Bonnot F (2003) Data analysis methods. In Hamon P, Seguin M, Perrier X and Glaszmann JC (eds) Genetic diversity of cultivated tropical plants. Science Publishers, Enfield, p. 43-76.

Popi J, Rajnpreht J, Kannenberg LW and Pauls KP (2000) Random amplified polymorphic DNA-based evaluation of diversity in the hierarchical, open-ended population enrichment maize breeding system. Crop Science 40: 619625.

Silva MGM, Viana AP, Gonçalves G M, Amaral Junior AT and Pereira MG (2009) Seleção recorrente intrapopulacional no maracujazeiro amarelo: alternativa de capitalização de ganhos genéticos. Ciência e Agrotecnologia 33: 170-176.

Souza E and Sorrells ME (1991) Relationships among 70 North American oat germplasms. II. Cluster analysis using qualitative characters. Crop Science 31: 605-612.

Taamalli W, Geuna F, Banfi R, Bassi D, Daoud D and Zarrouk M (2006) Agronomic and molecular analyses for the characterisation of accessions in Tunisian olive germplasm collections. Electronic Journal of Biotechnology 9: 467481.

Tardin FD, Pereira MG, Gabriel APC, Amaral Júnior AT and Souza Filho GA (2007) Selection index and molecular markers in reciprocal recurrent selection in maize. Crop Breeding and Applied Biotechnology 7: 225-233.

Townsend MS and Henning JA (2005) Potential heterotic groups in hop as determined by AFLP analysis. Crop Science 45: 1901-1907.

Viana AP, Pereira TNS, Pereira MG, Souza MM, Maldonado JFM and Amaral Júnior AT (2003) Diversidade genética entre genótipos comerciais de maracujazeiro amarelo (Passiflora edulis f. flavicarpa) e entre espécies nativas de Passiflora determinada por marcadores RAPD. Revista Brasileira de Fruticultura 25: 489-493.

Viana AP, Pereira TNS, Pereira MG, Amaral Júnior AT, Souza MM and Maldonado JFM (2004) Parâmetros genéticos em populações de maracujazeiro amarelo. Revista Ceres 51: 541-551. 